\title{
Penerapan Fuzzy Logic untuk Menentukan Minuman Susu Kemasan Terbaik dalam Pengoptimalan Gizi
}

\author{
Auliah Khoirun Nisa ${ }^{1, \text { a) }}$, Muhammad Abdy ${ }^{1, \text { b) }}$ dan Ahmad Zaki ${ }^{1, \text { b) }}$ \\ ${ }^{1}$ Jurusan Matematika, Fakultas Matematika dan Ilmu Pengetahuan Alam \\ Universitas Negeri Makassar \\ a) muh.abdy@unm.ac.id \\ b) ahmadzaki@unm.ac.id \\ c) auliahkhn99@gmail.com
}

\begin{abstract}
Abstrak. Penelitian terapan ini bertujuan untuk membangun model Penentuan Minuman Susu Kemasan Terbaik dengan variabel pertimbangan adalah harga dan nutrisi. Langkah-langkah yang digunakan pada penelitian ini yaitu fuzzifikasi, penentuan aturan fuzzy, inferensi fuzzy dengan metode mamdani, dan defuzzifikasi. Data yang digunakan adalah data yang diambil dari survey langsung di lapangan yang dilakukan oleh peneliti di salah satu supermarket di makassar. Hasil dari penelitian ini adalah susu kemasan sampel 16 yang menjadi susu kemasan yang paling cocok untuk direkomendasikan kepada masyarakat karena memiliki nutrisi tinggi dan harga yang terjangkau.
\end{abstract}

Kata Kunci: Fuzzy logic, Mamdani, Susu, Harga, Nutrisi

Abstract. This applied research aims to build a model of determining the best packaged milk with consideration variables are price and nutrition. The steps used in this research are fuzzification, fuzzy rule determination, fuzzy inference with mamdani method, and defuzzification. The data used are data taken from direct field surveys conducted by researchers in one of the supermarkets in Makassar. The results of this study is sample 16 packaged milk which is the most suitable packaged milk to recommended because it has high nutrition and affordable prices.

Keywords: Fuzzy logic, Mamdani, Milk, Price, Nutrition

\section{PENDAHULUAN}

Logika fuzzy pertama kali diperkenalkan oleh Jan Lukasiewicz pada tahun 1930, serta pertama kali dipromosikan oleh Lotfi Zadeh pada tahun 1965 melalui jurnal "Fuzzy set". Logika fuzzy terdiri dari tiga tahap utama: fuzzifikasi, inferensi dan defuzzifikasi (Azahar et al., 2013). Logika fuzzy mempunyai konsep sebagian, dimana logika fuzzy memungkinkan nilai keanggotaan antara 0 dan 1. Logika Fuzzy memungkinkan untuk memodelkan dengan lebih efisien, misalnya logika biner hanya memungkinkan untuk menyatakan bahwa kopi panas atau dingin, sedangkan logika fuzzy memungkinkan untuk membedakan antara semua kemungkinan fluktuasi suhu: sangat panas, suam-suam kuku, dingin, sangat dingin, dan lain-lain (Catro et al., 2009). Logika fuzzy dapat membantu menyelesaikan ketidakpastian antara satu kriteria dengan kriteria lainnya. Oleh karena itu, logika fuzzy sering digunakan dalam berbagai penelitian mutu makanan dan minuman. Salah satu minuman yang kaya nutrisi adalah Susu.

Kandungan nutrisi yang ada dalam susu adalah protein, karbohidrat, lemak, kalium, dan vitamin. Susu juga dikenal masyarakat sebagai salah satu sumber kalsium yang berguna untuk pembentukan tulang dan mencegah osteoporosis bagi orang lanjut usia. Susu telah menjadi salah satu jenis minuman yang banyak digemari oleh semua jenis kalangan. Mulai dari anakanak hingga lanjut usia. Di samping itu, susu mudah didapatkan di berbagai tempat dari kios pinggir jalan hingga supermarket. Olahan susu siap minum biasanya dikemas dalam kemasan 
kotak ataupun botol. Susu siap minum tersebut biasanya diproduksi dengan berbagai jenis rasa dan tawaran tambahan menarik seperti lebih rendah lemak, lebih tinggi kalsium dan lain-lain.

Konsumen dihadapkan dengan berbagai pilihan merek susu yang menjadi salah satu pertimbangan pemilihan susu. Selain mempertimbangkan masalah kandungan nutrisi di dalamnya, konsumen juga mempertimbangkan masalah harga. Seperti pendapat dari Sweeney et al (2001) yang dikutip oleh Muharam (2011) menyatakan bahwa, dalam membeli suatu produk, konsumen tidak hanya mempertimbangkan kualitasnya saja, tetapi juga memikirkan kelayakan harganya. Hal ini sesuai dengan penelitian yang telah dilakukan oleh Amelia Natasya, Iskandarini, dan Emalisa pada tahun 2018 menyatakan bahwa alasan pembelian minuman dalam hal ini thai green tea saat pertama kali didominasi oleh rasa haus kemudian diikuti oleh harga yang terjangkau. Ditambah, fokus perhatian konsumen minuman tersebut didominasi oleh kepraktisan dalam mengkonsumsi kemudian diikuti oleh harga. Susu siap minum telah beredar di pasaran dengan begitu banyak merek serta berbagai tingkatan harga dan kandungan nutrisi.

\section{KAJIAN TEORI}

\section{Himpunan Fuzzy}

Himpunan fuzzy adalah cabang dari matematika yang tertua, yang mempelajari proses bilang random: teori probailitas, statistik matematik, teori informasi dan lainnya. Penyelesaian masalah dengan himpunan fuzzy lebih mudah dari pada dengan mengunakan teori probabilitas (konsep pengukuran). Suatu himpunan dapat didefinisikan dengan menyatakan secara jelas atau mendaftarkan semua anggotaanggotanya.

Fungsi keanggotaan merupakan suatu kurva yang menunjukkan pemetaan titik-titik input data ke dalam nilai keanggotaannya (sering juga disebut dengan derajat keanggotaan). Penentuan fungsi keanggotaan pada suatu himpunan fuzzy bersifat subjektif, artinya penentuan fungsi keanggotaan untuk suatu konsep himpunan fuzzy dapat berbeda pada setiap orang. Subjektifitas tersebut disebabkan oleh perbedaan individu dalam mengekspresikan konsep-konsep abstrak. Meskipun bersifat subjektif, namun penentuan fungsi keanggotaan tersebut tidak dapat ditentukan secara bebas. Penentuannya harus merefleksikan konteks persoalan yang dipandang (Abdy, 2008).

Pemodelan yang tepat dibutuhkan karena model fuzzy sensitif terhadap jenis pendeskripsian himpunan fuzzy. Terdapat berbagai jenis pendeskripsian himpunan fuzzy, namun fungsi keanggotaan yang digunakan pada penelitian penulis yaitu representasi linier, segitiga dan trapesium.

\section{Logika Fuzzy}

Logika fuzzy diperkenalkan pertama kali pada tahun 1965 oleh Prof Lutfi A. Zadeh seorang peneliti di Universitas California di Barkley dalam bidang ilmu komputer. Professor Zadeh beranggapan logika benar salah tidak dapat mewakili setiap pemikiran manusia, kemudian dikembangkanlah logika fuzzy yang dapat mempresentasikan setiap keadaan atau mewakili pemikiran manusia. Perbedaan antara logika tegas dan logika fuzzy terletak pada keanggotaan elemen dalam suatu himpunan. Jika dalam logika tegas suatu elemen mempunyai dua pilihan yaitu terdapat dalam himpunan atau bernilai 1 
yang berarti benar dan tidak pada himpunan atau bernilai 0 yang berarti salah. Sedangkan dalam logika fuzzy, keanggotaan elemen berada di interval $[0,1]$.

Beberapa alasan digunakannya logika fuzzy adalah konsep logika fuzzy mudah dimengerti karena menggunakan bahasa alami yang telah dipahami oleh manusia.

\section{Sistem Fuzzy}

Penjelasan tahapan sistem fuzzy adalah sebagai berikut:

\section{Fuzzifikasi}

Menurut Wang (1997:105), fuzzifikasi didefinisikan sebagai pemetaan dari himpunan tegas ke himpunan fuzzy. Kriteria yang harus dipenuhi pada proses fuzzifikasi adalah semua anggota pada himpunan tegas harus termuat dalam himpunan fuzzy, tidak terdapat gangguan pada input sistem fuzzy yang digunakan harus bisa mempermudah perhitungan pada sistem fuzzy.

2. Aturan Fuzzy

Aturan yang digunakan pada himpunan fuzzy adalah aturan if-then. Proposisi fuzzy dibedakan menjadi dua, proposisi fuzzy atomic dan proposisi fuzzy compound. Proposisi fuzzy atomic adalah pernyataan single dimana $x$ sebagai variabel linguistik dan $A$ adalah himpunan fuzzy dari $x$. Proposisi fuzzy compound adalah gabungan dari proposisi fuzzy atomic yang dihubungkan dengan operator "or", "and", dan "not". (Wang, 1997:62-63)

3. Inferensi Fuzzy

Inferensi fuzzy merupakan tahap evaluasi pada aturan fuzzy. Tahap evaluasi dilakukan berdasarkan penalaran dengan menggunakan input fuzzy dan aturan fuzzy sehingga diperoleh output berupa himpunan fuzzy.

Salah satu jenis inferensi fuzzy yaitu metode Mamdani. Metode Mamdani pertama kali diperkenalkan oleh Ibrahim Mamdani pada tahun 1975. Metode ini merupakan metode yang paling sederhana dan paling sering digunakan untuk penelitian dibandingkan metode yang lain. Input dan output pada metode mamdani berupa himpunan fuzzy (Sri, 2002:98). Metode Mamdani menggunakan fungsi implikasi min dan agregasi max sehingga metode Mamdani juga disebut dengan metode MIN-MAX (min-max inferencing). Keluaran untuk $n$ aturan metode Mamdani didefinisikan sebagai

$$
\mu_{B^{K}}(y)=\max \left[\min \left[\mu A_{1}^{k}\left(x_{i}\right), \mu A_{2}^{k}\left(x_{i}\right)\right]\right]_{k}
$$

Untuk $k=1,2,3,4, \ldots n, A_{1}^{k}$ dan $A_{2}^{k}$ menyatakan himpunan fuzzy pasangan anteseden ke-k , dan $B^{k}$ adalah himpunan fuzzy konsekuen ke- $k$. (Sri dan Hari, 2013).

\section{Defuzzifikasi}

Defuzzifikasi merupakan proses yang berkebalikan dengan proses pada fuzzifikasi. Wang (1997:108) mendefinisikan defuzzifikasi sebagai pemetaan dari himpunan fuzzy $(B)$ ke himpunan tegas. Himpunan fuzzy yang dimaksud disini adalah hasil output yang diperoleh dari hasil inferensi. Pada proses 
defuzzifikasi ada tiga kriteria yang harus dipenuhi yaitu masuk akal, perhitungannya sederhana dan kontinu.

5. Pengujian Sistem Fuzzy

Tahap pengujian dilakukan untuk menguji apakah diagnosis yang dilakukan sudah sesuai atau belum. Pengujian yang dilakukan dalam penelitian ini dengan menghitung keakurasian sistem. Keakurasian sistem didapat dari perbandingan antara hasil jumlah data yang sesuai dengan kenyataan dengan jumlah seluruh data.

\section{Toolbox Fuzzy pada Aplikasi Komputer yang Digunakan}

Aplikasi yang digunakan merupakan perangkat lunak yang digunakan sebagai bahasa pemrograman tingkat tinggi. Aplikasi ini digunakan untuk komputasi, visualisasi dan pemrograman. Aplikasi ini telah digunakan oleh peneliti-peneliti dari berbagai wilayah di dunia. Sampai saat ini program-program pada aplikasi ini masih terus diperbaharui. Pemrograman pada aplikasi ini sering digunakan untuk pengembangan algoritma matematika dan pengembangan, pensisteman, simulasi dan prototype, analisis, eksplorasi dan visualisasi data, scientific dan engineering, pengembangan aplikasi berbasis grafik dan pembuatan Graphical User Interface (GUI). Dalam aplikasi tersebut terdapat sekumpulan tool yang membantu dalam merancang model fuzzy untuk diaplikasikan dalam berbagai bidang yang disebut Fuzzy Logic Toolbox.

\section{Susu Kemasan}

Susu adalah salah satu sumber nutrisi yang berasal dari hewan. Susu yang paling sering dijumpai adalah susu sapi dan susu kambing. Susu memiliki berbagai macam nutrisi di dalamnya mulai dari protein, karbohidrat, lemak, mineral, vitamin-vitamin dan lainnya. Susu juga dikenal masyarakat sebagai salah satu sumber kalsium yang berguna untuk pembentukan tulang dan mencegah osteoporosis bagi orang lanjut usia. Susu telah menjadi salah satu jenis minuman yang banyak digemari oleh semua jenis kalangan. Mulai dari anak-anak hingga lanjut usia. Susu biasanya mudah didapatkan di berbagai tempat dari kios pinggir jalan hingga supermarket. Olahan susu siap minum biasanya dikemas dalam kemasan kotak ataupun botol. Susu siap minum tersebut biasanya diproduksi dengan berbagai jenis rasa dan tawaran tambahan menarik seperti lebih rendah lemak, lebih tinggi kalsium dan lain-lain.

Konsumen dihadapkan dengan berbagai pilihan merek susu yang menjadi salah satu pertimbangan pemilihan susu. Selain mempertimbangkan masalah kandungan nutrisi di dalamnya, konsumen juga mempertimbangkan masalah harga. Seperti pendapat dari Sweeney et al (2001) yang dikutip oleh Muharam (2011) menyatakan bahwa, dalam membeli suatu produk, konsumen tidak hanya mempertimbangkan kualitasnya saja, tetapi juga memikirkan kelayakan harganya.

\section{METODE PENELITIAN}

Penelitian ini adalah penelitian terapan dengan mengkaji matematis produk susu dengan menggunakan logika fuzzy. Data dari penelitian ini diambil dari produk susu siap minum yang diperoleh dari supermarket dan minimarket di lokasi penelitian. Penelitian 
ini menggunakan 33 data sampel susu kemasan sebagai objek amatan. Kandungan nutrisi yang diambil adalah lemak $(\mathrm{L})$, protein $(\mathrm{P})$, karbohidrat $(\mathrm{K})$, natrium $(\mathrm{N})$, kalium (I) dan kalsium (C) yang kemudian diakumulasi dalam nutrisi total (NT). Langkahlangkah yang ditempuh agar tujuan penelitian dapat tercapai sebagaimana diharapkan adalah dengan mengumpulkan data berupa kandungan nutrisi dan harga dari produk minuman susu kemudian menganalisis data penelitian dengan model mamdani dengan bantuan program FIS (Fuzzy Inference System) pada aplikasi komputer.

\section{HASIL PENELITIAN}

\section{Pengolahan Data Menggunakan Metode Fuzzy Mamdani}

Data kandungan nutrisi dan harga dari setiap sampel ditunjukkan dalam Tabel 1.

TABEL 1. Data kandungan nutrisi dan harga

\begin{tabular}{|c|c|c|c|c|c|c|c|c|}
\hline $\begin{array}{c}\text { No } \\
\text { sampel }\end{array}$ & $\begin{array}{c}\text { Harga } \\
(\mathrm{Rp})\end{array}$ & $\begin{array}{c}\mathrm{L} \\
(\mathrm{g})\end{array}$ & $\begin{array}{l}\mathrm{P} \\
(\mathrm{g})\end{array}$ & $\begin{array}{l}\mathrm{K} \\
(\mathrm{g})\end{array}$ & $\mathrm{N}(\mathrm{g})$ & $\mathrm{I}(\mathrm{g})$ & $\mathrm{C}(\mathrm{g})$ & NT $(g)$ \\
\hline 1 & 9600 & 2.5 & 3 & 16 & 0.105 & 0.256 & 0.222 & 22.083 \\
\hline 2 & 9600 & 2.5 & 3 & 28 & 0.105 & 0.256 & 0.389 & 34.250 \\
\hline 3 & 9600 & 2 & 3 & 18 & 0.105 & 0.256 & 0.222 & 23.583 \\
\hline 4 & 4600 & 6 & 6 & 9 & 0.04 & 0.4 & 0.222 & 21.662 \\
\hline 5 & 5300 & 3.5 & 6 & 22 & 0.05 & 0.36 & 0.222 & 32.132 \\
\hline 6 & 5500 & 7 & 7 & 12 & 0.1 & 0.37 & 0.222 & 26.692 \\
\hline 7 & 5500 & 6 & 6 & 20 & 0.075 & 0.28 & 0.222 & 32.577 \\
\hline 8 & 5500 & 4.5 & 5 & 23 & 0.12 & 0.27 & 0.166 & 33.057 \\
\hline 9 & 5500 & 5 & 5 & 24 & 0.125 & 0.3 & 0.222 & 34.647 \\
\hline 10 & 5500 & 5 & 6 & 25 & 0.095 & 0.26 & 0.222 & 36.577 \\
\hline 11 & 5500 & 3 & 5 & 22 & 0.11 & 0.32 & 0.222 & 30.652 \\
\hline 12 & 4900 & 3.5 & 7 & 21 & 0.035 & 0.343 & 0.256 & 32.134 \\
\hline 13 & 4900 & 4 & 5 & 18 & 0.06 & 0.15 & 0.2003 & 27.410 \\
\hline 14 & 4900 & 4 & 6 & 24 & 0.045 & 0.26 & 0.166 & 34.472 \\
\hline 15 & 4200 & 4 & 4 & 23 & 0.085 & 0.4 & 0.222 & 31.707 \\
\hline 16 & 4200 & 4.5 & 5 & 36 & 0.04 & 0.22 & 0.222 & 45.982 \\
\hline 17 & 6900 & 3 & 6 & 21 & 0.05 & 0.33 & 0.333 & 30.714 \\
\hline 18 & 6900 & 2.5 & 5 & 19 & 0.115 & 0.26 & 0.333 & 27.209 \\
\hline 19 & 5500 & 3 & 3 & 19 & 0.1 & 0.1 & 0.055 & 25.255 \\
\hline 20 & 5500 & 4 & 3 & 24 & 0.06 & 0.1 & 0.055 & 31.215 \\
\hline 21 & 4200 & 3 & 4 & 16 & 0.075 & 0.23 & 0.222 & 23.527 \\
\hline 22 & 4200 & 3 & 4 & 15 & 0.075 & 0.24 & 0.278 & 22.593 \\
\hline 23 & 5400 & 2 & 7 & 20 & 0.125 & 0.36 & 0.278 & 29.763 \\
\hline 24 & 6700 & 2.5 & 5 & 24 & 0.105 & 0.31 & 0.723 & 32.638 \\
\hline 25 & 12900 & 3 & 7 & 24 & 0.07 & 0.1 & 0.389 & 34.559 \\
\hline 26 & 4400 & 3.5 & 3 & 23 & 0.065 & 0.25 & 0.278 & 30.093 \\
\hline 27 & 4400 & 3 & 3 & 21 & 0.063 & 0.24 & 0.1669 & 27.47 \\
\hline 28 & 8000 & 1.5 & 2 & 37 & 0.115 & 0.1 & 0.278 & 40.993 \\
\hline 29 & 8000 & 1.5 & 2 & 37 & 0.065 & 0.1 & 0.166 & 40.832 \\
\hline
\end{tabular}




\begin{tabular}{ccccccccc}
\hline $\begin{array}{c}\text { No } \\
\text { sampel }\end{array}$ & $\begin{array}{c}\text { Harga } \\
(\mathrm{Rp})\end{array}$ & $\begin{array}{c}\mathrm{L} \\
(\mathrm{g})\end{array}$ & $\begin{array}{c}\mathrm{P} \\
(\mathrm{g})\end{array}$ & $\begin{array}{c}\mathrm{K} \\
(\mathrm{g})\end{array}$ & $\mathrm{N}(\mathrm{g})$ & $\mathrm{I}(\mathrm{g})$ & $\mathrm{C}(\mathrm{g})$ & $\mathrm{NT}(\mathrm{g})$ \\
\hline 31 & 8000 & 1.5 & 1 & 37 & 0.18 & 0.1 & 0.166 & 39.947 \\
32 & 3000 & 2.5 & 2 & 16 & 0.05 & 0.1 & 0.166 & 20.817 \\
33 & 3000 & 2 & 2 & 15 & 0.055 & 0.1 & 0.166 & 19.322 \\
\hline
\end{tabular}

Data yang diperoleh dalam penelitian ini menggunakan metode fuzzy mamdani. Terdapat lima tahapan pada metode fuzzy mamdani dalam memperoleh output yaitu penentuan fuzzy set, fuzzifikasi, pembentukan aturan fuzzy, inferensi dan defuzzifikasi.

a. Menentukan Variabel Fuzzy dan Semesta Pembicaraan

Semesta pembicaraan dari tiap variabel ditentukan berdasarkan data-data yang diperoleh dari hasil penelitian. Didefinisikan himpunan universal dari harga susu kemasan, nutrisi susu kemasan, dan rekomendasi susu kemasan. Harga dan Nutrisi masing-masing dinyatakan dalam interval harga $=[0,15000]$ dan nutrisi $=$ $[0,50]$.

\section{b. Melakukan Fuzzifikasi}

Berdasarkan variabel dan domain himpunan fuzzy yang telah disusun tersebut, maka langkah selanjutnya menentukan fungsi keanggotaan untuk masing masing variabel dan menghitung nilai atau derajat keanggotaan berdasarkan fungsi keanggotaan yang telah ditentukan. Himpunan fuzzy beserta fungsi keanggotaan dari variabel harga dan nutrisi akan dipresentasikan berdasarkan data yang telah diperoleh.

Untuk harga didefinisikan menjadi 5 tingkat keanggotaan yaitu sangat murah (MU), murah (CM), mahal (MA), dan sangat mahal (SM). Demikian juga dengan kandungan nutrisi, didefinisikan menjadi sangat rendah (Clinical), rendah (Critical), sedang (BS), tinggi (S), sangat tinggi (OP). Sedangkan untuk rekomendasi susu kemasan didefinisikan menjadi 3 tingkat keanggotaan yaitu tidak direkomendasikan (NR), kurang direkomendasikan (JR), direkomendasikan (R), sangat direkomendasikan (HR).

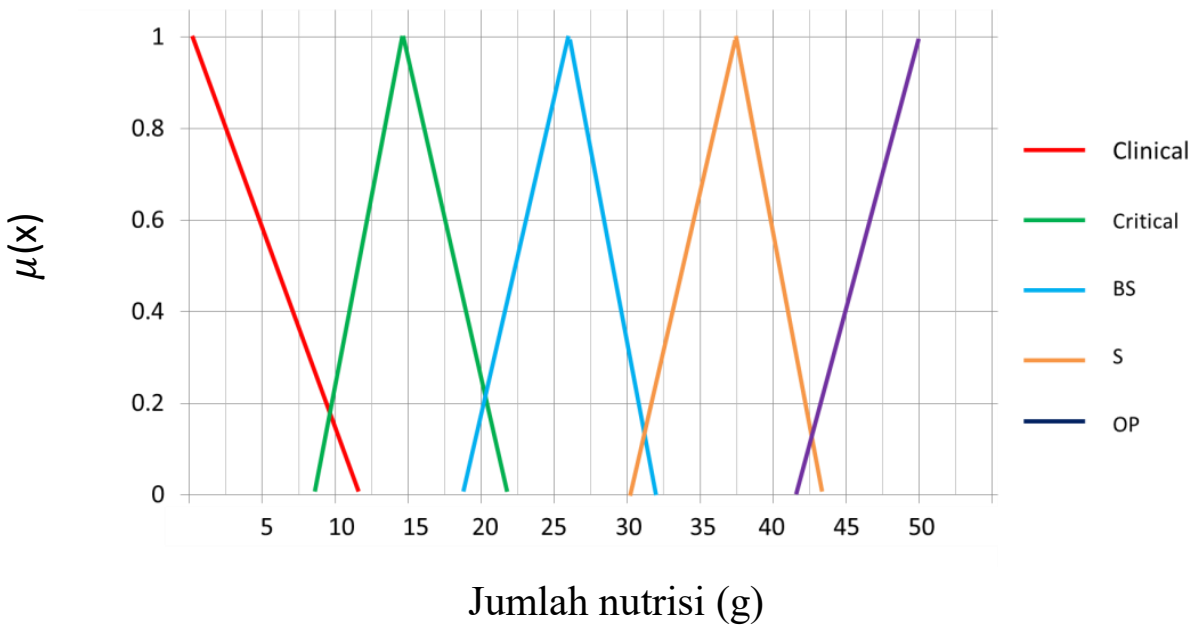

GAMBAR 1. Grafik Tingkat Keanggotaan Nutrisi 


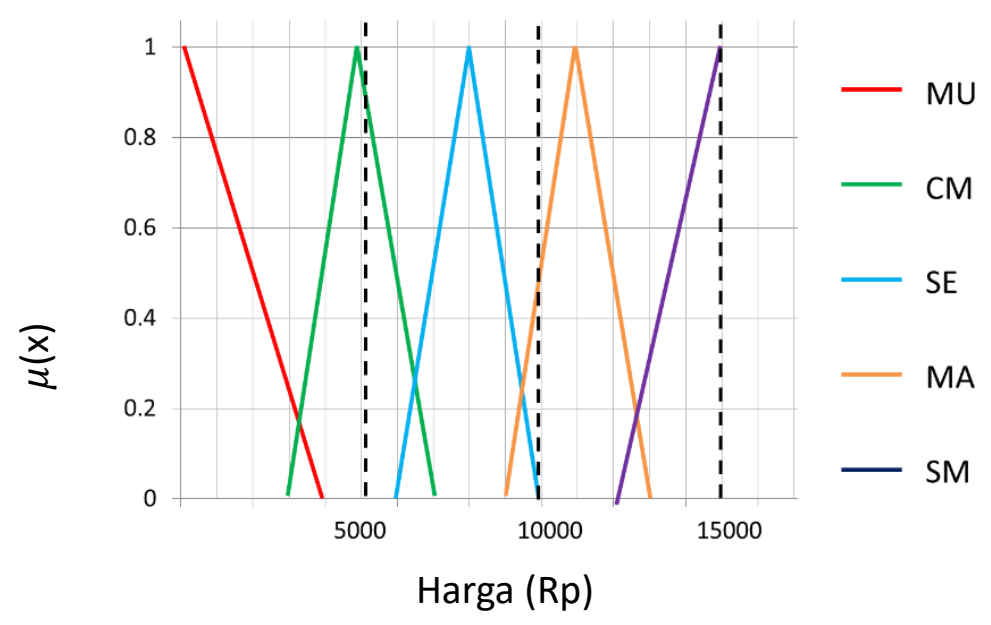

GAMBAR 2. Grafik Tingkat Keanggotaan Harga

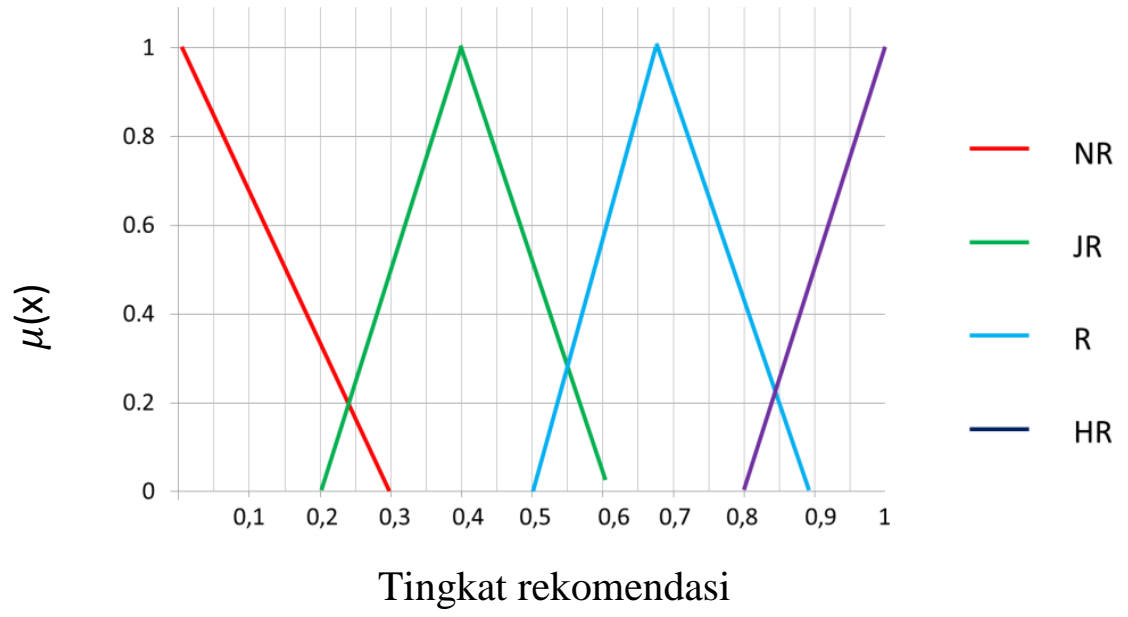

GAMBAR 3. Grafik Tingkat Keanggotaan Rekomendasi Susu Kemasan

Untuk nomor sampel 1 pada tabel 1, dengan harga 9600 dan NT 22,083. Akan dicari tingkat keanggotaan rekomendasi susu yaitu $\mu(x)$ dan $\mu(y)$ dengan $\mathrm{x}=$ 22,083 dan

$\mathrm{y}=9600$. Dari hasil perhitungan, didapatkan

$$
\begin{array}{ll}
\mu_{\text {Clinical }}(22,083)=0 & \mu_{M U}(9600)=0 \\
\mu_{\text {Critical }}(22,083)=0 & \mu_{M U}(9600)=0 \\
\mu_{B S}(22,083)=\frac{22,083-19}{7}=0,44 & \mu_{S E}(9600)=\frac{10000-9600}{2000}=0,2 \\
\mu_{\text {Critical }}(22,083)=0 & \mu_{M A}(9600)=\frac{9600-9000}{2000}=0,3 \\
\mu_{\text {Critical }}(22,083)=0 & \mu_{S M}(9600)=0
\end{array}
$$

c. Pembentukan aturan fuzzy

Tahap selanjutnya yang akan dilakukan setelah menentukan fungsi keanggotaan dari masing masing variabel yaitu menyusun aturan aturan logika fuzzy. Berdasarkan data yang ada, diperoleh aturan aturan sebagai berikut dengan sangat 
murah (MU), murah (CM), mahal (MA), dan sangat mahal (SM). Demikian juga dengan kandungan nutrisi, didefinisikan menjadi sangat rendah (Clinical), rendah (Critical), sedang (BS), tinggi (S), sangat tinggi (OP). Sedangkan untuk rekomendasi susu kemasan didefinisikan menjadi 3 tingkat keanggotaan yaitu tidak direkomendasikan (NR), kurang direkomendasikan (JR), direkomendasikan (R), sangat direkomendasikan (HR).

d. Melakukan inferensi dengan metode mamdani

1) Berdasarkan aturan-aturan yang telah dibuat, aturan yang digunakan pada sampel nomor 1 adalah R13 dan R18, yaitu

[R13] IF harga sedang (SE) AND kandungan nutrisinya sedang (BS) THEN kurang direkomendasikan (JR).

[R18] IF harga mahal (MA) AND kandungan nutrisinya sedang (BS) THEN tidak direkomendasikan (NR).

Selanjutnya menghitung predikat dari setiap aturan dengan fungsi implikasi Min, dengan $\mu_{B S}(22,083)=0,44 ; \mu_{S E}(9600)=0,2 ; \mu_{M A}(9600)=0,3$ adalah sebagai berikut:

$\alpha_{13}=\min \left[\mu_{S E}(9600), \mu_{B S}(22,083)\right]=\min [0,2 ; 0,44]=0,2$

$\alpha_{18}=\min \left[\mu_{M A}(9600), \mu_{B S}(22,083)\right]=\min [0,3 ; 0,44]=0,3$

2) Komposisi aturan

Melakukan komposisi aturan dari hasil aplikasi fungsi implikasi dari setiap aturan dengan menggunakan metode Max untuk melakukan komposisi antar semua aturan.
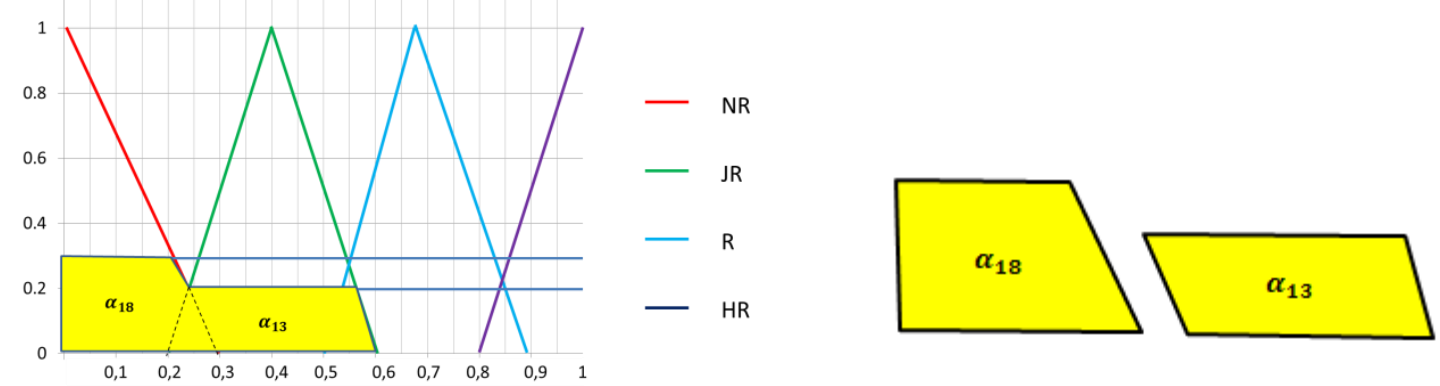

GAMBAR 4. Komposisi Aturan Fuzzy

Akan dicari daerah perpotongan untuk NR dan JR. Maka dengan aturan tingkat rekomendasi sebelumnya didapatkan bahwa daerah implikasi adalah

$$
\mu(z)=\left\{\begin{array}{c}
0 ; z \leq 0 \text { atau } z \geq 0,6 \\
0,3 ; 0<z<0,21 \\
\frac{0,3-z}{0,3} ; 0,21 \leq z \leq 0,24 \\
0,2 ; 0,24<z \leq 0,56 \\
\frac{0,6-z}{0,2} ; 0,56<z \leq 0,6
\end{array}\right.
$$


e. Defuzzifikasi

Defuzzifikasi diperoleh dengan cara menghitung momen dan luas daerah hasil impilasi. Terlebih dahulu menyederhanakan fungsi komposisi

Sehingga menjadi

$$
\mu(z)=\left\{\begin{array}{c}
0 ; z \leq 0 \text { atau } z \geq 0,6 \\
0,3 ; 0<z<0,21 \\
1-3,33 z ; 0,21 \leq z \leq 0,24 \\
0,2 ; 0,24<z \leq 0,56 \\
3-5 z ; 0,56<z \leq 0,6
\end{array}\right.
$$

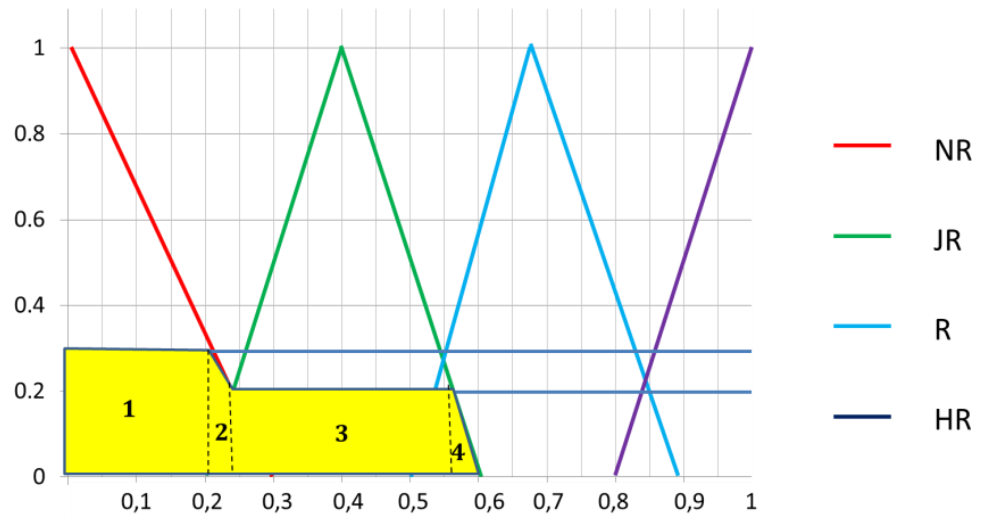

(a)

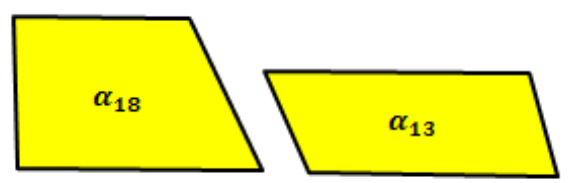

(b)

GAMBAR 5 Komposisi Aturan Fuzzy dengan Pembagian Empat Daerah

$$
\begin{aligned}
& \mathbf{M}_{1}=\int_{0}^{0,21}(0,3) z d z=\int_{0}^{0,21} 0,3 z d z=0,\left.15 z^{2}\right|_{0} ^{0,21}=0,006 \\
& \mathbf{M}_{2}=\int_{0,21}^{0,24}(1-3,33 z) z d z=\int_{0,21}^{0,24} z-3,33 z^{2} d z=\frac{z^{2}}{2}-\left.\frac{3,33 z^{3}}{3}\right|_{0,21} ^{0,24}=0,002 \\
& \mathbf{M}_{3}=\int_{0,24}^{0,56}(0,2) z d z=\int_{0,24}^{0,56} 0,2 z d z=0,\left.1 z^{2}\right|_{0,24} ^{0,56}=0,026 \\
& M_{4}=\int_{0,56}^{0,6}(3-5 z) z d z=\int_{0,56}^{0,6} 3 z-5 z^{2} d z=\frac{3 z^{2}}{2}-\left.\frac{5 z^{3}}{3}\right|_{0,56} ^{0,6}=0,005
\end{aligned}
$$

Kemudian hitung luas tiap daerah di Gambar 5(b)

$$
\begin{aligned}
\mathrm{A} \alpha_{13} & =(0,6-0,3) \times 0,2=0,3 \times 0,2=0,06 \\
\mathrm{~A} \alpha_{18} & =(0,2 \times 0,3)+\frac{(0,3-0,1) \times 0,2}{2} \\
& =0,06+0,015 \\
& =0,075
\end{aligned}
$$

Sehingga didapatkan titik pusat yaitu

$$
\begin{aligned}
z^{*} & =\frac{\int \mu_{x}(z) \cdot z d z}{\int \mu_{x}(z) d z} \\
& =\frac{\mathrm{M}_{1}+\mathrm{M}_{2}+\mathrm{M}_{3}+\mathrm{M}_{4}}{A \alpha_{13}+A \alpha_{18}}
\end{aligned}
$$




$$
\begin{aligned}
& =\frac{0,006+0,002+0,026+0,005}{0,06+0,075} \\
& =\frac{0,039}{0,135} \\
& =\frac{0,039}{0,135} \\
& =0,288
\end{aligned}
$$

\section{Analisis Penegasan Fuzzy Menggunakan Aplikasi Komputer}

Data mentah dari variabel input, harga dan nutrisi dikelompokkan menjadi nilai tegas yang selanjutnya dikonversikan ke dalam himpunan fuzzy. Aturan fuzzy yang berlaku dipilih dan dieliminasi untuk menghasilkan output bergantung pada nilai-nilai variabel input. Nilai fuzzy dari variabel output dihasilkan dengan menggunakan metode mamdani. Pada proses defuzzifikasi, nilai fuzzy dari output dikonversikan kembali ke dalam nilai tegas.

Pada penelitian ini, dibahas bagaimana menentukan susu kemasan dengan harga dan nutrisi yang sesuai bagi konsumen dengan penerapan logika fuzzy dengan bantuan FIS (Fuzzy Inference System) pada aplikasi komputer. Langkah-langkahnya adalah sebagai berikut:

1. Terlebih dahulu ditentukan input dan output yang diinginkan. Pada kasus ini ditentukan harga susu kemasan dan kandungan nutrisinya sebagai input. Sedangkan untuk outputnya adalah susu kemasan yang direkomendasikan untuk konsumen.

2. Selanjutnya didefinisikan himpunan universal dari harga susu kemasan, nutrisi susu kemasan, dan rekomendasi susu kemasan. Harga dan Nutrisi masing-masing dinyatakan dalam interval harga $=[0,15000]$ dan nutrisi $=[0,50]$.

3. Langkah selanjutnya adalah fuzzifikasi yaitu dengan mendefinisikan tingkat keanggotaan dari masing-masing input dan output. Untuk harga didefinisikan menjadi 5 tingkat keanggotaan yaitu sangat murah (MU), murah (CM), mahal (MA), dan sangat mahal (SM). Demikian juga dengan kandungan nutrisi , didefinisikan menjadi sangat rendah (Clinical), rendah (Critical), sedang (BS), tinggi (S), sangat tinggi (OP). Sedangkan untuk rekomendasi susu kemasan didefinisikan menjadi 3 tingkat keanggotaan yaitu tidak direkomendasikan (NR), kurang direkomendasikan (JR), direkomendasikan (R), sangat direkomendasikan (HR).

4. Langkah selanjutnya adalah menentukan aturan fuzzy yang akan digunakan untuk menentukan rekomendasi susu kemasan untuk konsumen.

5. Tahap terakhir adalah defuzzifikasi yaitu menghitung derajat keanggotaan untuk masing-masing sampel. Pada tahap ini, akan dilakukan perhitungan derajat keanggotaan dari setiap sampel dengan kandungan nutrisi dan harga yang dimiliki masing-masing sampel. Substitusikan nilai kandungan nutrisi sampel 1 dan harga sampel 1 pada kotak input maka akan muncul derajat keanggotaan pada kolom rekomendasi seperti yang ditunjukkan pada Gambar 6. Hasil tersebut adalah derajat keanggotaan rekomendasi sampel 1. 


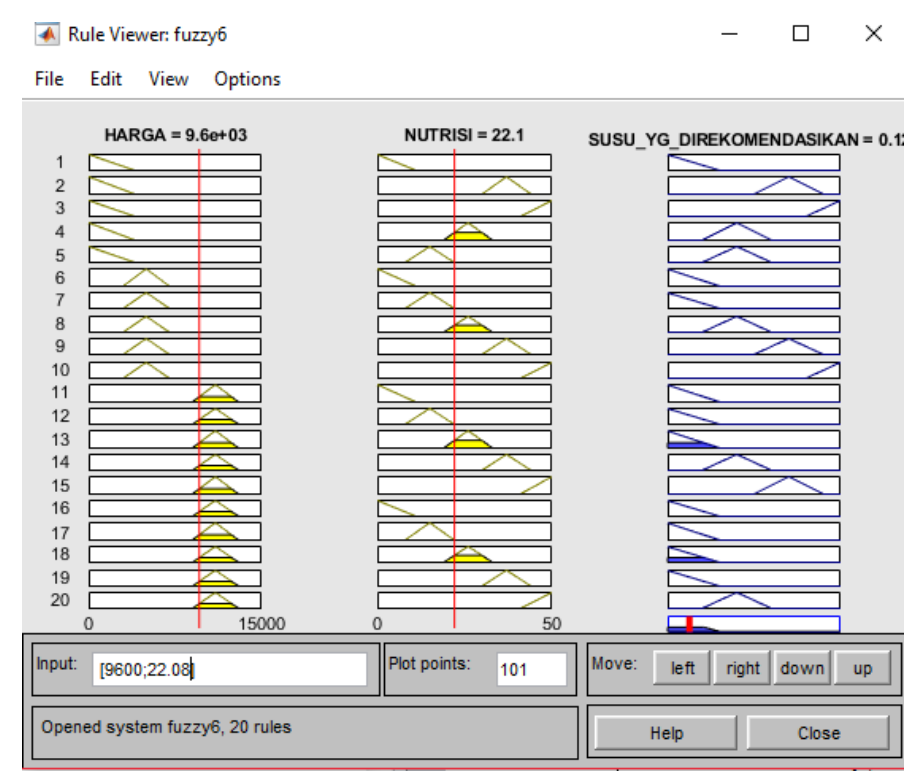

GAMBAR 6 Perhitungan Derajat Keanggotaan Rekomendasi Sampel 1

Selanjutnya mensubstitusikan nutrisi dan harga sampel 1 yaitu [9600;22.08] pada bagian input, diperoleh derajat keanggotaan rekomendasi susu kemasan sampel 1 adalah 0,1 . Selanjutnya dengan cara yang sama lakukan pada 32 sampel susu kemasan yang lain. Hasil derajat keanggotaan dari 33 sampel susu sampel dapat dilihat pada Tabel 2 yang telah disusun berdasarkan urutan rekomendasinya

TABEL 2 Urutan Derajat Keanggotaan Setiap Sampel Susu Kemasan

\begin{tabular}{lllll}
\hline $\begin{array}{l}\text { No } \\
\text { sampel }\end{array}$ & $\begin{array}{l}\text { Harga } \\
(\mathrm{Rp})\end{array}$ & $\mathrm{NT}(\mathrm{g})$ & $\begin{array}{l}\text { Derajat } \\
\text { Keanggotaan }\end{array}$ & Kategori \\
\hline 16 & 4200 & 45.983 & 0.92 & $\mathrm{HR}$ \\
14 & 4900 & 34.472 & 0.66 & $\mathrm{R}$ \\
8 & 5500 & 33.057 & 0.55 & $\mathrm{R}$ \\
7 & 5500 & 32.578 & 0.5 & $\mathrm{R}$ \\
9 & 5500 & 34.648 & 0.5 & $\mathrm{R}$ \\
10 & 5500 & 36.578 & 0.5 & $\mathrm{R}$ \\
11 & 5500 & 30.653 & 0.5 & $\mathrm{JR}$ \\
25 & 12900 & 34.560 & 0.5 & $\mathrm{JR}$ \\
32 & 3000 & 20.817 & 0.5 & $\mathrm{JR}$ \\
33 & 3000 & 19.322 & 0.5 & $\mathrm{JR}$ \\
12 & 4900 & 32.134 & 0.44 & $\mathrm{JR}$ \\
6 & 5500 & 26.693 & 0.4 & $\mathrm{JR}$ \\
13 & 4900 & 27.410 & 0.4 & $\mathrm{JR}$ \\
15 & 4200 & 31.708 & 0.4 & $\mathrm{JR}$ \\
19 & 5500 & 25.256 & 0.4 & $\mathrm{JR}$
\end{tabular}


Nisa ,Abdy, \& Zaki

\begin{tabular}{lllll}
\hline $\begin{array}{l}\text { No } \\
\text { sampel }\end{array}$ & $\begin{array}{l}\text { Harga } \\
(\mathrm{Rp})\end{array}$ & $\mathrm{NT}(\mathrm{g})$ & $\begin{array}{l}\text { Derajat } \\
\text { Keanggotaan }\end{array}$ & Kategori \\
\hline 20 & 5500 & 31.216 & 0.4 & JR \\
21 & 4200 & 23.528 & 0.4 & JR \\
22 & 4200 & 22.593 & 0.4 & JR \\
23 & 5400 & 29.763 & 0.4 & JR \\
26 & 4400 & 30.093 & 0.4 & JR \\
27 & 4400 & 27.470 & 0.4 & JR \\
24 & 6700 & 32.639 & 0.39 & JR \\
2 & 9600 & 34.251 & 0.27 & JR \\
28 & 8000 & 40.993 & 0.27 & JR \\
29 & 8000 & 40.832 & 0.27 & JR \\
30 & 8000 & 40.927 & 0.27 & JR \\
31 & 8000 & 39.947 & 0.27 & JR \\
17 & 6900 & 30.714 & 0.19 & NR \\
1 & 9600 & 22.084 & 0.1 & NR \\
3 & 9600 & 23.584 & 0.1 & NR \\
4 & 9600 & 21.663 & 0.1 & NR \\
\hline
\end{tabular}

Keterangan:

NR : Tidak direkomendasikan

JR : Kurang direkomendasikan

$\mathrm{R}$ : Direkomendasikan,

HR : sangat direkomendasikan.

Berdasarkan output yang telah diperoleh di tabel 2, terlihat bahwa susu instan sampel 16 memiliki derajat keanggotaan yang paling besar yaitu 0.92 , sehingga rekomendasi susu kemasan yang cocok untuk konsumen adalah susu kemasan sampel 16 karena memiliki kandungan nutrisi yang tinggi dan harga yang terjangkau.

\section{PEMBAHASAN}

Prosedur yang dilakukan pada penelitian ini mengacu pada penelitian Safitri (2015) yang berjudul Aplikasi Logika Fuzzy dalam Pemilihan Makanan Mie Instan. Safitri membahas tentang pemilihan makanan mie instan dengan menggunakan logika fuzzy. Pada penelitian tersebut, Safitri menggunakan aplikasi untuk menganalisis data. Penelitian ini menggunakan metode yang sama dengan penelitian Safitri (2015) yaitu dengan menggunakan teori logika fuzzy mamdani. Input dan output yang digunakan juga sama walaupun berbeda objek penelitian.

Penerapan logika fuzzy pada minuman susu sebelumnya telah dilakukan oleh Santoso, dkk (2010) juga melakukan penelitian berjudul Penerapan Logika Fuzzy pada Penilaian Mutu Susu Segar. Santoso, dkk (2010) mengamati variabel dalam penilaian mutu susu 
segar dengan menggunakan 6 variabel yaitu warna (putih kekuningan, putih dan putih kebiruan), rasa (cream y flavou $r$, swee flavour, dan salty flavou $r$ ), aroma (creamy odo $r$ dan cheesy odor ), $\mathrm{pH}$ (tinggi, sedang, agak rendah, dan rendah), protein (baik, sedang, dan jelek), tes resazurin (baik, sedang dan jelek). Sedangkan variabel input yang digunakan pada hasil penelitian ini adalah kandungan nutrisi yang tercantum pada tabel nutrisi yaitu; lemak $(\mathrm{L})$, protein $(\mathrm{P})$, karbohidrat $(\mathrm{K})$, natrium $(\mathrm{N})$, kalium (I) dan kalsium(C) yang kemudian diakumulasi dalam nutrisi total (NT).

Pada penelitian ini data yang digunakan untuk simulasi berupa data yang diperoleh dari hasil pengamatan langsung dari Lotte Mart, Mall Panakkukang. Hasil simulasi diperoleh bahwa sampel 16 memiliki derajat keanggotaan yang paling besar yaitu 0.92, sehingga rekomendasi susu kemasan yang cocok untuk konsumen adalah susu kemasan sampel 16 karena memiliki kandungan nutrisi yang tinggi dan harga yang terjangkau.

\section{KESIMPULAN}

Susu kemasan sampel 16 merupakan susu kemasan yang paling baik untuk direkomendasikan kepada para konsumen karena memiliki kandungan nutrisi yang tinggi dengan harga yang terjangkau setelah dilakukan langkah-langkah dalam penentuan keputusan pemilihan susu kemasan. Model pemilihan seperti ini sangat diperlukan untuk para konsumen agar dapat mengidentifikasi dan memilih makanan dengan harga dan kandungan nutrisi yang sesuai untuk dikonsumsi.

\section{DAFTAR PUSTAKA}

A'yun, K. (2015). Optimisasi Sistem Fuzzy pada Diagnosis Kanker Payudara Menggunakan Citra Mammogram yang Diimplementasikan dengan Graphicah User Interface (GUI). Skripsi. Universitas Negeri Yogyakarta.

Abdy, M. (2008). Dasar-dasar Teori Himpunan Dasar Kabur dan Logika Kabur. Edisi I. Badan Penerbit UNM. Makassar.

Azahar, T. M., I.,Ratnawati., Rasyidah, S. N., \& Nadiah, N.A. (2013). Fuzzy Logic Application for Odor Detection. International Journal of Engineering \& Technology, 13(5): 1-4.

Castro, A., dan Arcay, B. (2009). Fuzzy Logic Applied to Biomedical Image Analysis. Spain : University of A Coruña.

Kastaman, R., Zain, S., \& Prayudo, S.B. (2007). Penerapan Logika Fuzzy pada Penilaian Mutu Teh Hitam Orthodox. Skripsi. Bogor: Institut Pertanian Bogor.

Klir, G.J., Clair, U.S \& Yuan, B.(1997). Fuzzy Set Theory Foundations and Application. New Jersey:Prentice Hall International.

Kusumadewi, S. (2002). Analisis dan Desain Sistem Fuzzy Menggunakan Toolbox $M A T L A B$. Yogyakarta: Graha Ilmu.

Kusumadewi, Sri. dan Purnomo, Hari. (2013). Aplikasi Logika Fuzzy untuk Pendukung Keputusan. Ed 2. Yogyakarta: Graha Ilmu.

Muharam, A.S. (2011). Analisis Pengaruh Desain Kemasan Produk dan Daya Tarik Iklan terhadap Brand Awareness dan Dampak pada Minat Beli Konsumen 
(Studi pada konsumen Susu Kental Manis Frisian Flag di Kota Semarang). Skripsi. Semarang: Universitas Semarang.

Naba, A. (2009). Belajar Cepat Fuzzy Logic Menggunakan Matlab. Yogyakarta: ANDI.

Rivasti, R. (2009). Penerapan Logika Fuzzy pada Penilaian Mutu Teh Hitam (Studi Kasus di PTPN XII Kebun Teh Kertowono, Lumajang). Skripsi. Malang: Universitas Brawijaya.

Safitri, W. dan Abadi, A.M. (2015). Aplikasi Fuzzy Logic dalam Pemilihan Makanan Mie Instan. Skripsi. Yogyakarta: Universitas Negeri Yogyakarta.

Wang, L.X.(1997). A Course in Fuzzy System and Control International Edition, United States of America: Prentice-Hall International.

Zadeh, L.A., (1978). Fuzzy sets as a basis for a theory of possibility, Fuzzy sets and systems, 1, 3-28, 